\title{
Gambaran Pasien Reumatoid Artritis di RSUD Arifin Achmad Riau Province 2015 - 2019
}

\author{
Jelita Sri Agustin ${ }^{1 *}$, Huriatul Masdar ${ }^{2}$, Asrizal ${ }^{3}$
}

\begin{abstract}
Rheumatoid Arthritis (RA) is a chronic autoimmune disease that causes tissue damage, deformity, and death if not treated immediately. The aim of this study to description of RA patients in the Regional General Hospital (RSUD) Arifin Achmad Riau Province 2015 - 2019. The results showed that total cases was 55 cases with the more common in female $(87,3 \%)$ with most age group was $46-55$ years $(34,5 \%)$ and the main complaints were joint pain (85,5\%). Rheumatoid arthritis patients with laboratory examinations were nonreactive rheumatoid factor (RF) levels by 20 patients out of 30 patients, levels of Anti-Citrullinated Protei Antibodies (ACPA) or Immunoglobulin G anti-Cyclic Citrulinated Protein (IgG anti-CCP) reactive by 3 patients out of 4 patients, levels C-Reactive Protein (CRP) abnormal by 18 patients out of 21 patients and levels Erythrocyte Sedimentation Rate (ESR) abnormal by 20 patients out of 23 patients. The results also showed that the most pharmacological therapy given was corticosteroid $(87,3 \%)$.
\end{abstract}

Keyword : Rheumatoid Arthritis, rheumatoid factor, Anti-citrullinated protein antibody, pharmacological therapy.

Artritis Reumatoid (AR) adalah penyakit autoimun yang ditandai oleh inflamasi sistemik kronik dan progresif, serta sendi merupakan target utama. Artritis reumatoid juga bisa menyerang organ lain seperti kulit, jantung, paru-paru dan mata sehingga AR termasuk ke dalam kelompok penyakit autoimun non spesific organ. Manifestasi klinik yang khas dari AR adalah poliartritis sistemik terutama mengenai sendi-sendi kecil pada tangan dan kaki. ${ }^{1}$ Artritis reumatoid dapat mengakibatkan penderitaan bagi pasien tersebut karena rasa nyeri yang dialami, serta keterbatasan dalam beraktifitas sehingga mempengaruhi kualitas hidup dan dapat meningkatkan angka kematian. ${ }^{1}$

\footnotetext{
* Correspondent author: email: jelitasriagustin@gmail.com

1 Fakultas Kedokteran Universitas Riau, Pekanbaru, Riau, Indonesia

2 KJFD Histologi Fakultas Kedokteran Universitas Riau, Pekanbaru, Riau, Indonesia

${ }_{3}$ KJFD/KSM Ilmu Penyakit Dalam Fakultas Kedokteran Universitas Riau/ RSU Arifin Achmad Provinsi Riau, Indonesia
}

Menurut World Health Organization (WHO) prevalensi penyakit AR di dunia sekitar 0,3\% - 1\%. ${ }^{2}$ Menurut Arthritis Foundation tahun 2015 sebanyak 22\% atau lebih dari 50 juta orang dewasa di Amerika Serikat berusia lebih dari 18 tahun di diagnosa artritis. Berdasarkan data tersebut, sekitar 3\% atau 1,5 juta orang dewasa mengalami AR. ${ }^{3}$ Data epidemiologi di Indonesia didapatkan prevalensi AR sebesar 0,1\% - 0,2\%, sedangkan di Pulau Sumatera sebanyak $7,7 \%$ di diagnosa penyakit sendi pada tahun 2018, berdasarkan data tersebut sekitar 0,7\% adalah AR. ${ }^{4,5}$ Data jumlah pasien AR di Rumah Sakit Umum Daerah (RSUD) Arifin Achmad Provinsi Riau sampai saat ini masih belum memiliki jumlah pasti. Insiden atritis rematoid lebih banyak dialami oleh wanita berkisar antara 0,2 - 0,4 per 1000 populasi, sedangkan laki-laki hanya $0,1-0,2$ per 1000 populasi, dengan rentang usia antara 25-50 tahun. ${ }^{6,7}$

Diagnosis artritis reumatoid di Indonesia menggunakan kriteria diagnosis menurut American College of Rheumatology/Europan League Against Rheumatism (ACR/EULAR) tahun 2010. Berdasarkan kriteria tersebut tercantum beberapa 
kriteria yaitu tentang keterlibatan sendi, reaktan fase akut, dan lama sakitnya, namun kriteria ini tidak terlalu spesifik sehingga harus dilakukan pemeriksaan serologi berupa pemeriksaan rheumatoid factor (RF) dan anti-citrullinated protein antibodies (ACPA) atau Imunoglobulin G anti-cyclic citrullinates protein (IgG anti-CCP). ${ }^{1}$ Menurut da Mota et al tahun 2012, Pemeriksaan serologi yang memiliki sensitivitas cukup baik diantara kedua pemeriksaan tersebut yaitu pemeriksaan ACPA atau IgG anti-CCP, sensitivitasnya 70\%-75\% dan spesifisitas 95\%. ${ }^{8}$ Anti-citrullinated protein antibodies (ACPA) memiliki sensitivitas cukup baik dikarenakan dapat terdeteksi pada pasien AR sebelum munculnya tanda klinis pada pasien. ${ }^{6,9}$ Diagnosa AR juga dapat menggunakan kriteria klasifikasi dari American Rheumatism Association (ARA) tahun 1987, namun kriteria ini tidak dapat mendeteksi AR secara dini. ${ }^{10}$

The American College of Rheumatology Subscommitte on Rheumatoid Arthritis (ACRSRA) merekomendasikan inisiasi terapi DMARD (Disease-Modifying Antirheumatic Drugs) dalam memberikan terapi farmakologi pada pasien AR. Pemberian DMARD juga harus mempertimbangkan kepatuhan, beratnya penyakit, pengalaman dokter dan adanya penyakit penyerta pada pasien. Terapi farmakologi yang dapat diberikan selain DMARD adalah agen biologik, namun pemberian obat ini harus dipertimbangkan sesuai dengan kondisi pasien karena obat ini memiliki efek samping yang serius dan harganya cukup mahal. Terapi farmakologi lainnya adalah kortikosteroid dan Obat Anti Inflamasi Non-Steroid (OAINS). ${ }^{1,7}$
Penelitian mengenai gambaran pasien AR di RSUD Arifin Achmad Provinsi Riau sampai saat ini masih belum ada dan masih sedikitnya referensi data tentang kejadian penyakit AR di Indonesia. Berdasarkan penjelasan tersebut, peneliti tertarik untuk melakukan penelitian dengan judul Gambaran Pasien Artritis Reumatoid di Rumah Sakit Umum Daerah Arifin Achmad Provinsi Riau tahun 20152019.

\section{METODE}

Penelitian ini adalah penelitian deskriptif dengan pendekatan penelitian yang digunakan adalah retrospektif untuk melihat gambaran pasien AR di Rumah Sakit Umum Daerah Arifin Achmad Provinsi Riau tahun 2015-2019. Data penelitian ini diperoleh dari data sekunder yaitu rekam medis pasien AR. Penelitian ini dilakukan pada bulan Maret - Mei 2020. Penelitian ini telah dinyatakan lulus kaji etik oleh Unit Etik Penelitian Kedokteran dan Kesehatan Fakultas Kedokteran Universitas Riau dengan nomor B/19/ UN.19.5.1.1.8/UEPKK/2020. Populasi pada penelitian ini adalah seluruh pasien yang terdiagnosis penyakit artritis reumatoid di Rumah Sakit Umum Daerah Arifin Achmad Provinsi Riau tahun 20152019 dan seluruh populasi pada penelitian ini menjadi sampel penelitian (total sampling).

\section{HASIL}

Hasil penelitian ini didapatkan 55 kasus AR di Rumah Sakit Umum Daerah Arifin Achmad Provinsi Riau tahun 2015 - 2019. Distribusi frekuensi pasien AR berdasarkan jenis kelamin, usia, dan keluhan utama dapat dilihat pada tabel 1 berikut : 
Tabel 1. Distribusi frekuensi pasien AR berdasarkan jenis kelamin, umur dan keluhan utama di RSUD Arifin Achmad Provinsi Riau tahun 2015-2019

\begin{tabular}{lcc}
\hline Variabel & Frekuensi (n) & Persentase (\%) \\
\hline Jenis Kelamin & 7 & 12,7 \\
Laki-laki & 48 & 87,3 \\
Perempuan & & \\
Kelompok Umur & 5 & 9,1 \\
$=25$ tahun & 7 & 12,7 \\
$26-35$ tahun & 11 & 20 \\
$36-45$ tahun & 19 & 34,5 \\
$46-55$ tahun & 11 & 20 \\
$55-65$ tahun & 2 & 3,6 \\
$>65$ tahun & & 85,5 \\
Keluhan Utama & 47 & 5,5 \\
Nyeri sendi & 3 & 9 \\
Bengkak sendi & 5 & \\
Kaku sendi & & \\
\end{tabular}

Berdasarkan tabel 1 didapatkan bahwa kebanyakan pasien AR berjenis kelamin perempuan yakni 48 pasien (87,3\%) dengan kelompok umur pasien AR kebanyakan berumur 46-55 tahun yaitu 19 pasien $(34,5 \%)$ dan keluhan utama yang paling banyak adalah nyeri sendi sebanyak 47 pasien (85,8\%).

Tabel 2. Distribusi frekuensi pemeriksaan RF, ACPA, CRP dan LED pasien AR di RSUD Arifin Achmad Provinsi Riau tahun 2015-2019

\section{Variabel}

Rheumatoid Factor (RF)

Reaktif (= 20 IU.ml)

Non-reaktif $(<20 \mathrm{IU} / \mathrm{ml})$

Tidak diperiksa

ACPA atau IgG anti-CCP

Reaktif (= 20 IU.ml)

Non-reaktif $(<20 \mathrm{IU} / \mathrm{ml})$

Tidak diperiksa

C-Reactive Protein (CRP

Di atas normal $(=6 \mathrm{mg} / \mathrm{L}) \quad 18$

Normal $(<6 \mathrm{mg} / \mathrm{L})$

Tidak diperiksa

\section{Frekuensi (n)}

10

20

25

3

1

51

3

Laju Endap Darah (LED)

Laki-laki

Di atas normal $(=10 \mathrm{~mm} / \mathrm{jam}) \quad 2$

Normal $(<10 \mathrm{~mm} / \mathrm{jam}) \quad 0$

Tidak diperiksa $\quad 5$

Perempuan

$\begin{array}{lc}\text { Di atas normal }(=15 \mathrm{~mm} / \mathrm{jam}) & 18 \\ \text { Normal }(<15 \mathrm{~mm} / \mathrm{jam}) & 3\end{array}$

$\begin{array}{ll}\text { Normal }(<15 \mathrm{~mm} / \mathrm{jam}) & 3 \\ \text { Tidak diperiksa } & \end{array}$

$\begin{array}{ll}\text { Tidak diperiksa } & 27\end{array}$ 
Berdasarkan tabel 2 didapatkan kadar RF yang paling banyak adalah non-reaktif yaitu 20 dari 30 pasien yang dilakukan pemeriksaan RF. Kadar ACPA atau IgG anti-CCP paling banyak adalah reaktif yaitu 3 dari 4 pasien yang dilakukan pemeriksaan ACPA atau IgG anti-CCP. Kadar CRP paling banyak di atas normal yaitu 18 dari 21 pasien yang dilakukan pemeriksaan CRP dan kadar LED paling banyak di atas normal yaitu 20 dari 23 pasien yang dilakukan pemeriksaan LED.

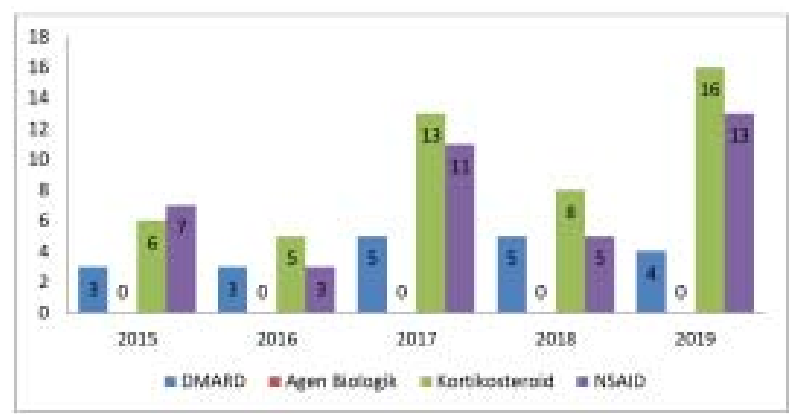

Gambar 1. Karakteristik terapi farmakologi pasien AR di RSUD Arifin Achmad Provinsi Riau tahun 2015- 2019

Berdasarkan gambar 1 didapatkan terapi farmakologi yang paling banyak digunakan adalah kortikosteroid yaitu sebanyak 48 pasien (87,3\%) dan tidak ada pasien AR yang mendapatkan terapi farmakologi berupa agen biologik. Terapi farmaologi yang diberikan merupakan terapi kombinasi

\section{PEMBAHASAN}

Merujuk dari hasil penelitian ini didapatkan 55 kasus AR yang didominasi dengan jenis kelamin perempuan sebanyak 48 pasien (87,3\%). Penelitian sebelumnya yang dilakukan di RSUD Dr. H. Abdul Moeloek Provinsi Lampung, pada penelitian tersebut didapatkan jumlah pasien AR sebesar 65,4 \% adalah perempuan dan 34,6 \% adalah laki-laki. ${ }^{12}$ Data lainnya yang dilakukan di Poliklinik Reumatologi RSUD Dr. Saiful Anwar Malang, dimana pada penelitian tersebut didapatkan jumlah pasien AR sebesar 85,2 \% adalah perempuan dan 14,8\% adalah laki-laki. ${ }^{13}$ Jenis kelamin termasuk salah satu faktor risiko dari AR, perempuan lebih berisiko terhadap penyakit AR karena dipengaruhi oleh hormone estrogen. Estrogen berpotensi menimbulkan sistem imun yang tidak baik, sehingga memperngaruhi kondisi dimana sistem imun salah mengenal dan justru menyerang jaringan tubuh sendiri. Hormon estrogen mempenharuhi kerja interleukin-17 (IL-17), dengan adanya defisiensi estrogen mengakibatkan depresi IL-17 dan meningkatkan terjadinya kerusakan pada tulang dan sendi. Hormone estrogen juga dapat meningkatkan produksi sitokin pro-inflamasi lain seperti IL-1, IL10, Interferon- (IFN-). Sitokin tersebut merupakan sitokin yang berperan terhadap pathogenesis AR. ${ }^{14}$

Berdasarkan hasil penelitian ini, AR didominasi pada kelompok umur 46-55 tahun sebanyak 19 pasien (34,5\%). Data ini sejalan dengan penelitian yang dilakukan di RSUD Dr. H. Abdul Moeloek Provinsi Lampung, didapatkan pasien AR yang paling banyak terjadi pada kelompok umur 47 - 53 tahun yaitu sebesar 25 pasien (32,1\%). ${ }^{12}$ Penelitian lain yang ini tidak jauh berbeda dengan penelitian yang dilakukan di wilayah kerja Puskesmas Danguang Danguang Payakumbuh, pada hasil penelitian tersebut didapatkan bahwa pasien AR yang paling banyak terjadi pada kelompok umur 56 - 65 tahun yaitu sebesar 26 pasien (83.9\%). ${ }^{15}$ Hasil penelitian ini didapatkan bahwa AR dominan pada usia menopause yaitu pada usia 45-55 tahun, hal ini berhubungan dengan terjadinta penurunan estrogen yang merupakan tanda terjadinya menopause pada perempuan. Penurunan kadar estrogen dapat meningkatkan sel $\mathrm{T}$ autoimun sehingga memicu terjadinya kegagalan toleransi sel T. ${ }^{16}$

Keluhan utama yang paling banyak dialami oleh pasien adalah nyeri sendi sebanyak 47 pasien (85,5\%). Kondisi ini sama dengan penelitian yang dilakukan di RSUD Dr. H. Abdul Moeloek Provinsi Lampung, pada penelitian tersebut didapatkan bahwa keluhan yang paling sering pada pasien AR adalah nyeri sendi yaitu sebanyak 83,3\%, kemudian diikuti keluhan kaku sendi sebanyak 10,3\% dan keluhan bengkak sendi sebanyak 6,4\%. ${ }^{12}$ Keluhan utama AR dapat berupa nyeri sendi dipengaruhi oleh adanya produksi sitokin pro-inflamasi oleh makrofag yang menyebabkan timbulnya keluhan nyeri. ${ }^{11}$

Pemeriksaan laboratorium seperti Rheumatoid Factor (RF), Anti Citrullinated Protein Antibodies (ACPA), C-Reactive Protein (CRP) dan Laju Endap Darah (LED) tidak dilakukan pada semua pasien. Hal ini berhubungan dengan kriteria yang 
paling banyak digunakan oleh klinisi yaitu kriteri ARA 1987. Kriteria tersebut belum dianjurkan dilakukan pemeriksaan ACPA, CRP dan LED, serta apabila sudah memenuhi 4 poin dari 7 poin yang ada maka sudah dapat didiagnosa sebagai AR tanpa dilakukan pemeriksaan RF. ${ }^{10}$

Berdasarkan hasil dari pasien yang dilakukan pemeriksaan laboratorium pada tabel 2 didapatkan 20 dari 30 pasien memiliki kadar RF non-reaktif. Penelitian sebelumnya yang dilakukan di Poliklinik Reumatologi RSUD Dr. Saiful Anwar Malang pada tahun 2019 terdapat perbedaan yakni kadar RF paling banyak adalah reaktif sebanyak 46 dari 88 pasien dan non-reaktif sebanyak 42 dari 88 pasien. ${ }^{13}$ Hasil penelitian ini juga tidak sejalan dengan penelitian yang dilakukan di RSUD Dr. Pringadi Medan, dimana didapatkan kadar RF paling banyak adalah reaktif yakni 24 dari 33 pasien dan non-reaktif sebanya 9 dari 33 pasien. ${ }^{17}$ Adanya perbedaan hasil penelitian ini berhubungan dengan pemeriksaan RF bukan merupakan pemeriksaan yang spesifik pada AR. Kadar RF yang tidak reaktif dapat menunjukkan gejala AR pada pasien tersebut masih ringan atau merupakan tanda suatu perbaikan. Hal lain yang dapat menyebabkan kadar RF non-reaktif yaitu pasien tersebut memiliki kadar antibodi RF yang sangat rendah sehingga tida dapat terdeteksi. ${ }^{18,19}$

Pasien yang dilakukan pemeriksaan ACPA didapatkan 3 dari 4 pasien yang memiliki kadar reaktif. Hasil penelitian ini sejalan dengan penelitian yang dilakukan di Poliklinik Reumatologi RSUD Dr. Saiful Anwar Malang pada tahun 2019 didapatkan kadar ACPA atau IgG anti-CCP paling banyak adalah reaktif yaitu sebanyak 65 dari 88 pasien dan non-reaktif sebanyak 23 dari 88 pasien. ${ }^{13}$ Banyaknya pasien yang tidak dilakukan pemeriksaan ACPA karena pada umumnya klinisi masih menggunakan kriteria ARA 1987 yang belum menganjurkan pemeriksaan ACPA, selain itu pemeriksaan ACPA masih tergolong mahal dan baru ditanggung oleh jaminan kesehatan beberapa tahun terakhir. ${ }^{6,8}$

Hasil pemeriksaan CRP didapatkan 18 pasien memiliki kadar CRP diatas normal dari 21 pasien yang dilakukan pemeriksaan CRP. Data ini sejalan dengan penelitian yang dilakukan di RSUD Dr. Pringadi Medan pada tahun 2011 didapatkan kadar CRP reaktif atau diatas normal sebanyak 22 dari 33 pasien dan kadar CRP non-reaktif sebanyak 11 dari
33 pasien. ${ }^{17}$. hal ini berhubungan dengan kadar CRP memuncak dalam 48-72 jam setelah terjadinya inflamasi dan akan segera kembali ke kadar normal. Jika pasien sudah melewati kadar puncak pemeriksaan CRP akan menjadi kurang bermakna. ${ }^{11}$ pemeriksaan CRP sedikit dilakukan juga ada hubungan dengan kriteria yang umum digunakan oleh klinisi yaitu ARA 1987.,68

Kadar LED pada pasien yang dilakukan pemeriksaan didapatkan 20 dari 23 pasien memiliki kadar diatas normal. Penelitian yang dilakukan di RSUD Dr. Pringadi Medan, pada penelitian tersebut didapatkan kadar LED diatas normal sebanyak 25 dari 33 pasien dan kadar LED normal sebanyak 8 dari 33 pasien. ${ }^{17}$ Kadar LED dapat meningkat selama inflamasi akut adanya kerusakan jaringan dan keganasan sehingga LED bukan merupakan pemeriksaan yang spesifik pada satu penyakit. ${ }^{20}$ Banyaknya pasien yang tidak dilakukan pemeriksaan LED berhubungan dengan kriteria yang digunakan klinisi yaitu ARA $1987 .{ }^{11}$

Terapi farmakologi yang diberikan pada pasien merupakan terapi kombinasi, dari hasil penelitian pada gambar 1 didapatkan pasien paling banyak diberikan kortikosteroid yaitu sebanyak 48 pasien (87,3\%). Penelitian ini berbeda dengan penelitian yang dilakukan di Instalasi Rawat Jalan Rumah Sakit PKU Muhammadiyah Yogyakarta didapatan bahwa pengobatan yang paling banyak adalah DMARD dan NSAID yaitu 12 pasien (40\%). ${ }^{21}$ Berdasarkan algoritma pengobatan yang berikan adalah OAINS kombinasi dengan kortikosteroid sebagai pengobatan simptomatik, jika terapi tersebut tidak mampu mengontrol keluhan dan tidak adanya perbaikan maka diberikan terapi kombinasi dengan DMARD. ${ }^{7}$ Hasil penelitian menunjukkan tidak adanya pasien yang diberikan terapi agen biologi, dikarenakan keluhan pasien masih mampu dikontrol dengan menggunaan pengobatan OAINS, kortikosteroid ataupun DMARD. Pengobatan agen biologi cukup mahal dan hanya bisa diberikan kepada pasien usia produktif karena mempertimbangan efek samping yang dapat timbul. Pengobatan agen biologi juga hanya bisa diberikan oleh konsultan rematologi. ${ }^{7}$ 


\section{SIMPULAN DAN SARAN}

Berdasarkan hasil penelitian dan pembahasan tentang gambaran pasien AR di RSUD Arifin Achmad Provinsi Riau tahun 2015 - 2019, dapat diambil simpulan bahwa setiap pemeriksaan laboratorium dan terapi yang diberikan berdasarkan kriteria yang digunakan oleh klinisi dan keluhan yang dialami oleh pasien dengan hasil pasien AR yang paling banyak berjenis kelamin perempuan 48 pasien (87,3\%), kelompok umur paling banyak adalah umur 46-55 tahun sebanyak 19 pasien (34,5\%), keluhan utama paling banyak berupa nyeri sendi sebanyak 47 pasien (85,5\%), kadar RF paling banyak yaitu non-reaktif sebanyak 20 dari 30 pasien yang dilakukan pemeriksaan RF, kadar ACPA atau IgG anti-CCP paling banyak yaitu reaktif sebanyak 3 dari 4 pasien yang dilakukan pemeriksaan ACPA, kadar CRP dan LED yang paling banyak adalah di atas normal masing masing berjumlah 18 dari 21 pasien yang dilakukan pemeriksaan CRP dan 20 dari 23 pasien yang dilakukan pemeriksaan LED. Terapi farmakologi yang paling banyak diberikan adalah kortikosteroid yakni 48 pasien (87,3\%). Berdasarkan penelitian ini disarankan dilakukan sosialiasi mengenai pemeriksaan ACPA atau IgG anti-CCP agar dapat mendeteksi secara dini sehingga membantu dalam proses terapi dan perlunya dilakukan penelitian lanjutan.

\section{DAFTAR PUSTAKA}

1. Suarjana I. Artritis reumatoid. In: Setiati S, Alwi I, Sudoyo A, Simadibta M, Setyohadi B, Syam A, editors. Buku Ajar Ilmu Penyakit Dalam. 6th ed. Jakarta: Interna Publishing FK UI; 2015. p. 313247.

2. World Health Organization. Chronic rheumatic conditions [Internet]. 2018 [cited 2020 Jan 16]. Available from: https://www.who.int/chp/topics/ rheumatic/en/

3. Arthritis Foundation. Scientific strategy 20152020 [Internet]. 2015 [cited 2018 Oct 30]. Available from: https://www.artrhitis.org/ documents/arthritis-foundation-scientificstrategy.pdf

4. Shah A, Clair EW St. Rheumatoid arthritis. In: Jameson JL, Kasper D, Longo DL, Fauci AS,
Hauser SL, Loscalzo J, editors. Principles of Internal Medicina. 19th ed. USA: McGraw-Hill Education; 2018. p. 2527-40.

5. Kementrian Kesehatan Republik Indonesia. Laporan Nasional Riset Kesehatan Dasar 2018. 2018;177-9.

6. Cope AP. Rheumatoid arthritis. In: Rich R, Fleisher T, Shearer W, Schroeder H, Frew A, Weyand C, editors. Clinical Imunology Principles an Practice. 5th ed. USA: Elsevier; 2019: p. 70520.

7. Perhimpunan Rheumatologi Indonesia. Diagnosis dan pengelolan rheumatoid arthritis. Jakarta: Perhimpunan Rheumatologi Indonesia; 2014. 2$22 \mathrm{p}$.

8. Da Mota LMH, Dos Santos Neto LL, De Carvalho JF, Pereira IA, Burlingame R, Ménard $\mathrm{HA}$, et al. The presence of anti-citrullinated protein antibodies (ACPA) and rheumatoid factor on patients with rheumatoid arthritis (RA) does not interfere with the chance of clinical remission in a follow-up of 3 years. Rheumatol Int. 2012;32(12):3807-12.

9. Nielen MMJ, Van Schaardenburg D, Reesink HW, Van De Stadt RJ, Van Der Horst-Bruinsma IE, De Koning MHMT, et al. Specific autoantibodies precede the symptoms of rheumatoid arthritis: a study of serial measurements in blood donors. Arthritis Rheum. 2004;50(2):380-6.

10.Pradana S. Sensitifitas dan spesifisitas kriteris ACR 1987 dan ACR/EULAR 2010 pada penderita artritis reumatoid di RSUP Dr. Kariadi Semarang. 2012;

11. Baratawidjaja KG, Rengganis I. Imunologi dasar. 12th ed. Jakarta: FK UI; 2018. 626-630 p.

12. Timori, Hardiansyah; Esfandiari, Firhat; Mandala Z. Gambaran karakteristik penderita rheumatoid arthritis di Bagian Penyakit Dalam RSUD Dr. H. Abdul Moeloek Provinsi Lampung 2013. 2014;1(1):4-7.

13. Suryana BPP, Sari RK, Tamayanti WD, Hasanah D. Hubungan antara parameter klinis dan laboratoris dengan status remisi penyakit pada pasien artritis reumatoid yang mendapat terapi metotreksat. Maj Kesehat. 2019;6(2):113-22. 
14. Moulton VR. Sex hormones in acquired immunity and autoimmune disease. Front Immunol. 2018;9(OCT):1-21.

15.Elsi M. Gambaran faktor dominan pencetus arthritis rheumatoid di wilayah kerja Puskesmas Danguang Danguang Payakumbuh tahun 2018. Menara Ilmu. 2018;XII(8):98-106

16. Desai MK, Brinton RD. Autoimmune disease in women: Endocrine transition and risk across the lifespan. Front Endocrinol (Lausanne). 2019;10(APR).

17.Atiqah F. Perbandingan sensitivitas dan spesifisitas kadar CRP dan LED pada pasien rheumatoid artritis di RSUD Dr. Pringadi, Medan. [SKRIPSI]. Medan: Universitas Sumatera Utara; 2011.
18. Ingegnoli F, Castelli R, Gualtierotti R. Rheumatoid factors: Clinical applications. Dis Markers. 2013;35(6):727-34.

19.Freeman J. Seronegative RA: what are the symptoms of seronegative RA [Internet]. 2018 [cited 2020 Jun 5]. Available from: https:// www.rheumatoidarthritis.org/ra/types/ seronegative/

20.Davis GM, Lantis KL, Finn WG. Laboratory hematology practice. USA: Blackwell; 2012: 638-644 p.

21. Rianiari U. Gambaran pengobatan dan kualitas hidup pada pasien rheumatoid arthritis di Instalasi Rawat Jalan RS PKU Muhammadiyah Yogyakarta. [SKRIPSI]. Yogyakarta: Universitas Gadjah Mada; 2014. 